\title{
Analysis of the Relationship Between Service Procedures, Capability of Service Officers, Speed of Service, and Environmental Comfort with the Level of Satisfaction of KB Acceptors
}

\author{
$1^{\text {st }}$ Sri Susanti \\ Politeknik Kesehatan Aisyiyah Banten \\ Jl. Raya Cilegon Km. 8 Pejaten, \\ Kramatwatu, Serang, Banten, \\ Indonesia \\ srisusanti80@gmail.com
}

\author{
$2^{\text {nd }}$ Ika Apriyanti \\ Politeknik Kesehatan Aisyiyah Banten \\ Jl. Raya Cilegon Km. 8 Pejaten, \\ Kramatwatu, Serang, Banten, \\ Indonesia
}

\author{
$3^{\text {rd }}$ Rd Deden Gumilar Nugraha \\ Politeknik Kesehatan Aisyiyah Banten \\ Jl. Raya Cilegon Km. 8 Pejaten, \\ Kramatwatu, Serang, Banten, \\ Indonesia
}

\begin{abstract}
Improving the quality of family planning services is carried out to assist family planning acceptors to achieve optimal individual health. In the effort to realize quality contraceptive services, it is necessary to provide the necessary facilities to support safe contraceptive services, competent health workers, speed in providing services and the comfort of the environment of the providers' facilities. contraceptive services. Study data for Alkon availability in health facilities in the JKN Era in Banten province in 2017 showed 22 health facilities in the city of Cilegon that had registered in $\mathrm{K}$ / 0 / KB were still found ALKON vacancies and health worker qualifications that had not been fulfilled to provide family planning services. From this data, this research needs to be done so that it is known how the level of satisfaction of Kb Acceptor Satisfaction in FKTP K / O / Kb Registered in Cilegon City in 2018. The research objective is to determine the relationship between service procedures, the ability of service personnel, speed of service, and environmental comfort with the level of satisfaction of KB acceptors in FKTP registered K / 0 / KB in the city of Cilegon. Cross-Sectional Method. Research sites are 27 health facilities. The population of all KB acceptors visiting health facilities in Cilegon who have registered $\mathrm{K} / \mathrm{O} / \mathrm{KB}$. The sample in this study was 200 respondents. This sampling technique uses accidental sampling. The results of this study are that there is a significant relationship between Service Procedures, Service Speed, Officer Capability and environmental comfort with the satisfaction of respondents using family planning services. The conclusions obtained that the main priorities in service improvement are adjusted to the findings of this study are: (1) Timeliness of service; (2) increment of staff competency in KIE activities; (3) improvement of governance in structuring facilities and infrastructure in health facilities; (4) Customer satisfaction training for health workers; (5) ongoing evaluation of the public performance of $\mathrm{KB}$ service providers in integrated health facilities $\mathrm{K} / 0$ / KB.
\end{abstract}

Keywords-Service Procedures, Capability, Officers, KB Acceptors

\section{INTRODUCTION}

Utilization of quality family planning services is an important element in achieving reproductive health services as stated in the ICPD program in Cairo in 1994. Where one point is that everyone has the right to obtain information and access to safe, effective contraceptive methods, acceptable and affordable [1], Talking about service quality, the size is not only determined by the service provider (Provider) but more is determined by the party served (acceptor), because they are the ones who enjoy the service so that they can measure the quality of service based on their expectations in meeting their satisfaction [2].

To improve the quality of public services, the government makes a rule that is used as a reference to measure the performance of public service units regularly. The decision was based on the Minister of Administrative Reform, Number: KEP / 25 / M.PAN / 2/2004 concerning general guidelines for service index satisfaction of public service units of government agencies, but the reality is that at present, public services provided by government officials are still widely found weakness so it does not meet the quality expected by the community. This is indicated by a large number of complaints felt by the public, such as complaints about service procedures that tend to be difficult, officers who are less disciplined and impolite, the environment is less comfortable for visitors, or even the implementation of service schedules that are often incorrect [3].

According to (Regulation of the Head of the National Population and Family Planning Board, 2017) Family Planning Health Facilities, hereinafter referred to as KB Health Facilities is a facility capable of providing contraceptive services, located and integrated in First Level Health Facilities (FKTP) and in Advanced Level Referral Health Facilities (FKRTL), is managed by the government including the military, police and private and non-governmental organizations and has been registered in the $\mathrm{K} / 0$ / $\mathrm{KB}$ data and in collaboration with the Health BPJS. Whereas $\mathrm{K} / 0$ / KB is data that contains the number of $\mathrm{KB}$ health facilities and their characteristics, the potential of existing and trained $\mathrm{KB}$ service personnel and equipment facilities in each $\mathrm{KB}$ health facilities throughout Indonesia.

Quality of service is said to be achieved if it can meet and exceed customer needs and expectations through continuous improvement of the entire process. Customers include patients, families, and others who come to get services. Every customer related to a health 
care institution has a desire or expectation for a product that is provided or produced by a health care provider. Today there are still many weaknesses in health service institutions so that they cannot meet the quality expected by the community. They have certain requirements for health service products/services. This requirement is expected to be fulfilled in whole or in part by health service provider institutions [4].

Quality improvement in family planning services is carried out to help family planning acceptors to achieve optimal individual health, also very significant in reducing fertility rates through increased use of contraceptives. The quality of family planning services and other reproductive health is how clients/acceptors of family planning are treated by a good service system. Service quality includes six aspects, namely the availability of contraceptive methods, the quality of the information provided to clients (acceptors), interpersonal relationships between service providers and acceptors, the technical capabilities of service personnel, advanced service mechanisms, and the accuracy of service delivery.

Furthermore, from the results of a study on the availability of Alkon in health facilities in the JKN Era in Banten province in 2017, at 30 health facilities in Tangerang and 22 health facilities in Cilegon that were registered in $\mathrm{K} / 0$ / KB, it was found that the ALKON vacancy was also found. unqualified qualifications of health workers to provide family planning services. The same thing was found from the results of an assessment conducted by the JSI Research and Training Institute in collaboration with BKKBN in 11 districts/cities in 2016 found that there were 45 percent of the Fasyankes sample having a contraceptive vacancy, some ALKON provided by BKKBN There were 29 Fasyankes experiencing a vacancy injection method and 21 percent have an implant method vacancy. so this causes the provider to not be able to give a choice of all the methods that should be offered. This will, of course, have a direct effect on the quality of services provided to the $\mathrm{KB}$ acceptor.

\section{METHOD}

The research design used in this study is CrossSectional study design. In this study the population is all family planning acceptors visiting 22 health facilities that have registered $\mathrm{K} / 0 / \mathrm{KB}$. Thus the number of samples to be taken is $200 / 22$ health facilities $=9$ samples per health facility. This sampling procedure uses accidental sampling, ie sampling that happened to be present at the time of the study.

\section{RESULT AND DISCUSSION}

\section{A. Univariate analysis}

TABLE 1. FREQUENCY DISTRIBUTION OF RESPONDENTS BASED ON SATISFACTION LEVEL OF KB ACCEPTORS IN FKTP REGISTERED K / O / KB IN CILEGON CITY IN 2018

\begin{tabular}{|c|c|c|c|}
\hline No & Satisfaction & Frequency & Percentage (\%) \\
\hline 1 & Dissatisfied & 14 & 7 \\
\hline 2 & Satisfied & 186 & 93 \\
\hline \multicolumn{2}{|c|}{ Total } & 200 & 100 \\
\hline
\end{tabular}

Based on table 1, still found respondents said they were dissatisfied with family planning services in FKTP registered $\mathrm{K} / 0$ / KB in the city of Cilegon by $7 \%$.

TABLE 2 DISTRIBUTION OF RESPONDENT FREQUENCY BASED ON KB ACCEPTOR SERVICE PROCEDURE, SPEED OF KB ACCEPTOR SERVICE, ABILITY OF KB ACCEPTANCE SERVICES, CONVENIENCE OF KB ACCEPTOR SERVICE PLACE IN FKTP K / O / KB REGISTERED IN CILEGON CITY IN 2018

\begin{tabular}{|c|c|c|c|}
\hline No & Variable & Frequency & Percentage (\%) \\
\hline 1 & Procedure Service & & 4 \\
\hline & Not Easy & 8 & 3 \\
\hline & Less Easy & 6 & 77 \\
\hline & Easy & 154 & 16 \\
\hline & Very Easy & 32 & 3 \\
\hline & Procedure Service & & 5.5 \\
\hline & Not Fast & 6 & 81.0 \\
\hline & Less Fast & 11 & 10.5 \\
\hline & Fast & 162 & 3.5 \\
\hline & Very Fast & 21 & 3.0 \\
\hline & Ability of Service & & 80.5 \\
\hline & Not Able & 7 & \\
\hline & Poor Able & 6 & 161 \\
\hline
\end{tabular}




\begin{tabular}{|c|c|c|c|}
\hline & Very Able & 26 & 13.0 \\
\hline 4 & Ability of Service & & 3.5 \\
\hline & Not Able & 7 & 3.0 \\
\hline & Poor Able & 6 & 80.5 \\
\hline & Able & 161 & 13.0 \\
\hline & Very Able & 26 & 3.5 \\
\hline 5 & Convenience of place & & 3.0 \\
\hline & Not Able & 7 & 80.5 \\
\hline & Poor Able & 6 & 13.0 \\
\hline & Able & 161 & 100 \\
\hline & Very Able & 26 & 200 \\
\hline
\end{tabular}

\section{B. Bivariate analysis}

TABLE 3. RELATIONSHIP BETWEEN SERVICE PROCEDURES AND LEVEL OF SATISFACTION OF FAMILY PLANNING ACCEPTORS IN FKTP REGISTERED K / 0 / KB IN BANTEN PROVINCE IN 2018

\begin{tabular}{|c|c|c|c|c|c|c|c|}
\hline \multirow{3}{*}{ Service Procedure } & \multicolumn{4}{|c|}{ Satisfaction } & \multirow{2}{*}{\multicolumn{2}{|c|}{ Number of }} & $P$-value \\
\hline & \multicolumn{2}{|c|}{ Not Satisfied } & \multicolumn{2}{|c|}{ Satisfied } & & & \\
\hline & $\mathrm{N}$ & $\%$ & $\mathrm{~N}$ & $\%$ & $\mathrm{~N}$ & $\%$ & \multirow[t]{6}{*}{0,000} \\
\hline Not Easy & 7 & 87.5 & 1 & 12.5 & 8 & 100 & \\
\hline Less Easy & 6 & 100 & 0 & 0 & 6 & 100 & \\
\hline Easy & 1 & 0.6 & 153 & 99.4 & 154 & 100 & \\
\hline \multirow[t]{2}{*}{ Very Easy } & 0 & 0.0 & 32 & 100 & 32 & 100 & \\
\hline & 14 & 7.0 & 186 & 93 & 100 & 100 & \\
\hline
\end{tabular}

Based on table 3, shows that respondents who said it was not easy in the service procedure all said they were not satisfied by $100 \%$ of the services provided at comparing it with respondents who say it's easy to say dissatisfied by $0.6 \%$. The statistical test results obtained $P$-value 0,000 with a confidence level of $95 \%$, it can be concluded that there is a relationship between service procedures and satisfaction of family planning acceptors at K / 0 / KB Registered FKTP in Cilegon City in 2018
This study is also in line with (7) which states that service procedure is one of the factors or aspects contained in the delivery of services to the community. Ease of service stages provided to the community in terms of simplicity of service flow to determine the performance of service units. will cause convenience for the community towards health services and in the end will make patients feel satisfied with the services provided

TABLE 4. RELATIONSHIP BETWEEN SPEED OF SERVICE AND LEVEL OF KB ACCEPTOR SATISFACTION IN FKTP K / 0 / KB REGISTERED IN CILEGON CITY IN 2018

\begin{tabular}{|c|c|c|c|c|c|c|c|}
\hline \multirow{3}{*}{ Speed of } & \multicolumn{4}{|c|}{ Satisfaction } & \multirow{2}{*}{\multicolumn{2}{|c|}{ Number }} & $P$-value \\
\hline & \multicolumn{2}{|c|}{ Not Satisfied } & \multicolumn{2}{|c|}{ Satisfied } & & & \\
\hline & $\mathrm{N}$ & $\%$ & $\mathrm{~N}$ & $\%$ & $\mathrm{~N}$ & $\%$ & \multirow[t]{5}{*}{0,000} \\
\hline Not Fast & 6 & 100 & 0 & 0 & 6 & 100 & \\
\hline Less Fast & 8 & 72.7 & 3 & 27.3 & 11 & 100 & \\
\hline Fast & 0 & 0 & 162 & 100 & 162 & 100 & \\
\hline \multirow[t]{2}{*}{ Very Fast } & 0 & 0 & 21 & 100 & 21 & 100 & \\
\hline & 14 & 7.0 & 186 & 93 & 200 & 100 & \\
\hline
\end{tabular}


Based on the table 4, shows that respondents who did not get all services quickly $(100 \%)$ said they were not satisfied with the mop the service provided compared to Respondents who stated that the service in the fast category all expressed satisfaction with the services provided $(100 \%)$. The statistical test results obtained $P$ value 0,000 with a confidence level of $95 \%$, it can be concluded that there is a relationship between the speed of service with KB acceptor satisfaction.in FKTP Yang Registered K / 0 / KB in the city of Cilegon in 2018.

The results of the relationship test state that there is a relationship between service speed and respondent satisfaction. this is by [5] which states that because of the speed in service will cause a sense of satisfaction for the community towards health services. Quality health services must be provided within the allotted time. Vice versa if the speed of service perceived by patients is less then it will cause a sense of dissatisfaction in service.

This is supported by [6] which says that speed in service is considered good if in providing services more attentive to patient needs. Satisfaction arises from the first impression of the patient's admission to the nursing services provided.

TABLE 5. DISTRIBUTION SERVICES OFFICER RELATIONSHIP BETWEEN CAPABILITY LEVEL OF SATISFACTION WITH ACCEPTOR KB ON THE REGISTERED FKTP K / 0 / KB IN CILEGON 2018

\begin{tabular}{|c|c|c|c|c|c|c|c|}
\hline \multirow[t]{3}{*}{ Ability Service } & \multicolumn{4}{|c|}{ Satisfaction } & \multirow{2}{*}{\multicolumn{2}{|c|}{ Total }} & \multirow[t]{2}{*}{$\begin{array}{c}\text { Value } \\
P\end{array}$} \\
\hline & \multicolumn{2}{|c|}{ Not } & \multicolumn{2}{|c|}{ Satisfied } & & & \\
\hline & $\mathrm{N}$ & $\%$ & $\mathrm{~N}$ & $\%$ & $\mathrm{~N}$ & $\%$ & \multirow[t]{6}{*}{0,000} \\
\hline Disadvantaged & 7 & 100 & 0 & 0 & 7 & 100 & \\
\hline Less Capable & 6 & 100 & 0 & 0 & 6 & 100 & \\
\hline Capable & 1 & 0.6 & 160 & 99.4 & 161 & 100 & \\
\hline \multirow[t]{2}{*}{ Very Capable } & 0 & 0 & 26 & 100 & 26 & 100 & \\
\hline & 14 & 7.0 & 186 & 93 & 200 & 100 & \\
\hline
\end{tabular}

Based on table 5, shows that respondents who said officers were not able to service entirely (100\%) stated that they were dissatisfied with the services provided compared to patients who were able to provide an assessment of the ability of the officers. Almost all of them said they were satisfied with the services provided (99.4\%). The statistical test results obtained P-value of 0,000 with a confidence level of $95 \%$, it can be concluded that there is a relationship between the ability of services with the satisfaction of $\mathrm{KB}$ acceptors at FKTP Registered K / 0 / KB in Cilegon City in 2018.
Quality of service in a public service provider is highly dependent on the management of all its resources, besides being demanded the advancement of science and technology. One of the main supports of internal resources is the quality of internal services as a basic component of the ability of human resources with those owned by organizations engaged in services. So that it is seen as a very decisive element in providing satisfactory services to customers (customer satisfaction) [7]

TABLE 6. RELATIONSHIP BETWEEN ENVIRONMENTAL COMFORT AND KB ACCEPTOR SATISFACTION LEVEL AT FKTP YANG REGISTERED K / 0 / KB IN CILEGON CITY IN 2018

\begin{tabular}{|c|c|c|c|c|c|c|c|}
\hline \multirow{3}{*}{$\begin{array}{c}\text { Comfort } \\
\text { Environmental }\end{array}$} & \multicolumn{4}{|c|}{ Satisfaction } & \multirow{2}{*}{\multicolumn{2}{|c|}{ Amount of }} & \multirow{2}{*}{$\begin{array}{c}\text { Value } \\
P \\
\end{array}$} \\
\hline & \multicolumn{2}{|c|}{ Dissatisfied } & \multicolumn{2}{|c|}{ Satisfied } & & & \\
\hline & $\mathrm{N}$ & $\%$ & $\mathrm{~N}$ & $\%$ & $\mathrm{~N}$ & $\%$ & 0,000 \\
\hline Uncomfortable & 8 & 100 & 0 & 0 & 8 & 100 & \\
\hline Less comfortable & 5 & 55.6 & 4 & 44.4 & 9 & 100 & \\
\hline Comfortable & 1 & 0.7 & 150 & 99.3 & 151 & 100 & \\
\hline Very comfortable & 0 & 0 & 32 & 100 & 32 & 100 & \\
\hline & 14 & 7.0 & 186 & 93 & 200 & 100 & \\
\hline
\end{tabular}


Based on table 6, shows that respondents who said they were uncomfortable $100 \%$ said they were dissatisfied in receiving the services provided compared to respondents who said they were comfortable almost all of them said they were satisfied $(99.3 \%)$ of the services provided. Statistical test results obtained $P$ value of 0,000 with a confidence level of $95 \%$, it can be concluded that there is a relationship between service comfort and satisfaction of family planning acceptors at FKTP Registered K / 0 / KB in Cilegon City in 2018.

Sanders and Mc. Cormick (1993) in [8] comfort is a condition of feeling and is very dependent on the person experiencing the situation. We do not know the level of comfort that other people feel directly or observation but rather must ask the person directly about how comfortable they are. The theory of Comfort from Katherine Kolcaba is one of the Middle Range Theory of nursing that emphasizes the perfection of nursing practice through the comfort of life [9]. In this theory, there is an intervention variable which is the interaction of various forces that influence one's perception of overall comfort, namely experience, age, attitude, emotional status, support system, disease and financial prognosis (Kolcaba, 2003). Comfort has become the main goal of nursing because comfort healing can be obtained [9]

\section{CONCLUSIONS}

There is a significant relationship between Service Procedure, Service Speed, Officer Capability and environmental comfort with the satisfaction of respondents using family planning services.

From the results of this study it is suggested that the priority should be made in improving services adjusted to the findings of this study are: (1) Timeliness of services (2) improvement of staff competencies in IEC activities (3) improvement in governance of infrastructure and facilities in health facilities (4) training Customer satisfaction for health workers (5) ongoing evaluation of public performance of family planning service providers in integrated health facilities $\mathrm{K} / 0$ / KB.

\section{REFERENCES}

[1] Saefudin, Buku Panduan Pelayanan Kontrasepsi. Jakarta: Yayasan Bina Pustaka, 2013.

[2] Bharata, Dasar-Dasar Pelayanan Prima. Jakarta: Media Komutinda Gramedia, 2014.

[3] U. Chasanah, "Pengukuran Kinerja Berdasarkan Indeks Kepuasaan Masyarakat Pada Puskesmas Kalirungkut Surabaya," J. Ilmu Ris. Akunt., vol. 2, no. 3, 2013.

[4] A. Azwar, Pengantar Administrasi Kesehatan. Jakarta: Bina Rupa Aksara, 2010.

[5] Nurnawati, Mutu Pelayanan Kebidanan. Jakarta: Trans Info Media, 2010.

[6] J. Beneke, C. Hayworth, R. Hobson, dan Z. Mia, "Examining the effect of retail service quality dimensions on customer satisfaction and loyalty: The case of the supermarket shopper," Acta Commer., vol. 12, no. 1, hal. 27-43, 2012.

[7] V. A. J. of the A. M. S. Zeithaml, "Service quality, profitability, and the economic worth of customers: what we know and what we need to learn," J. Acad. Mark. Sci. 28(1)., vol. 28, no. 1, 2000.

[8] A. Shahjehan, B. Afsar, dan S. I. Shah, "Is organizational commitment-job satisfaction relationship necessary for organizational commitment-citizenship behavior relationships? A Meta-Analytical Necessary Condition Analysis," Econ. Res. Istraživanja, vol. 32, no. 1, hal. 2657-2679, 2019.

[9] T. Martha Raile Aligood, Introduction to nursing theory Its history, significance, and analysis. 2013.

[10] K. Kinabalu, "A Study on the Relationship between Customer Satisfaction and Employee Service Delivery at Sutera Sanctuary Lodges ' s Front Office Department at Kinabalu Park , Kundasang," vol. 9, 2014

[11] M. Science, N. Carolina, dan C. Hill, "Service Quality , Profitability, and the Economic Worth of Customers : What We Know and What We Need to Learn Service Quality , Profitability, and the Economic Worth of Customers: What We Know and What We Need to Learn," no. December 2000, 2015.

[12] S. M. Agritubella, "Kenyamanan Dan Kepuasan Pasien Dalam Proses Interaksi Pelayanan Keperawatan Di Rsud Petala Bumi," J. Endur., vol. 3, no. 1, hal. 42, 2018.

[13] T. Kepuasan, P. Rawat, J. Di, dan P. Lamper, "Analisis FaktorFaktor Yang Berhubungan Dengan Tingkat Kepuasan Pasien Rawat Jalan Di Puskesmas Lamper Tengah Kecamatan Semarang Selatan Kota Semarang," Public Heal. Perspect. J., vol. 1, no. 1, hal. 45-52, 2016.

[14] Sareong Kiki Miranti, "Faktor-faktor yang Berhubungan DenganKepuasan Pasien Rawat Jalan di Puskesmas Rantepao Kabupaten Toraja Utara," 2013.

[15] Kepmen PAN No. 63/M.PAN/7/2003, Pedoman Umum Penyusunan Indeks Kepuasan Masyarakat Unit Pelayanan Instansi Pemerintah. .

[16] Kepmen PAN No. 25/M.PAN/2/2004, Pedoman Umum Penyusunan Indeks Kepuasan Masyarakat Unit Pelayanan Instansi Pemerintah. 